\title{
Performance Assessment of the Developed Flux Powder on the Tensile and Hardness Properties of Steels Joints Using TIG-Welding
}

\author{
Sunday A. Afolalu ${ }^{1}$, Omolayo M. Ikumapayi ${ }^{2 *}$, Temitayo S. Ogedengbe ${ }^{3}$, Moses E. Emetere ${ }^{4}$ \\ ${ }^{1}$ Department of Mechanical Engineering, Covenant University, KM. 10 Idiroko Road, Canaan Land, Ota 112212, Nigeria \\ ${ }^{2}$ Department of Mechanical and Mechatronics Engineering, Afe Babalola University, Ado Ekiti 360101, Nigeria \\ ${ }^{3}$ Department of Mechanical Engineering, Elizade University, P.M.B, 002 Ilara Mokin 340271, Nigeria \\ ${ }^{4}$ Department of Physics, Covenant University, KM. 10 Idiroko Road, Canaan Land, Ota 112212, Nigeria
}

Corresponding Author Email: ikumapayi.omolayo@abuad.edu.ng

https://doi.org/10.18280/rcma.310306

Received: 29 May 2021

Accepted: 15 June 2021

\section{Keywords:}

nano-flux powder, hardness, tensile strength, tig-welding, steels, eggshell

\begin{abstract}
The conversion of waste to wealth has recently grossed high attention as it possesses the ability to boost the economy of any nation; hence, this research. In this study, the characterization and investigation of mechanical properties of nano- flux $(\mathrm{CaO})$ welding powder developed from bio-agrowaste (eggshell) was carried out. Mild, galvanized and stainless steel of plates and rods were used as parent metals for the experiment. Results obtained from hardness test in the base metal, weld joint and heat affected zone for the galvanized and mild steel plates with nano-flux powder gave the best hardness of 111.95 , $120.30,182.99$ and 206.21, 164.85, 110.56 BHN respectively. The tensile stress obtained both for mild and stainless steel was $88.14 \mathrm{MPa}$ while the tensile strain obtained for both plates were $0.0155 \mathrm{~mm} / \mathrm{mm}$. Microstructural analysis results shows an improvement in the structure, surface and patterns of the weld with the use of developed flux compared with imported flux. Hence eggshells can be recycled and used for developing flux powder for welding processes.
\end{abstract}

\section{INTRODUCTION}

Welding is a metal joining technique whereby at least two materials (mostly metals) are combined and makes a blend between these materials utilizing the use of heat with or without the utilization of pressure [1]. The choice of the weld depends on the proposed engineering stress on the weld and the welding process being used for the work [2]. Among the more pronounced welding types is Arc welding which has two major classifications viz Metal Inert Gas Welding (MIG) and Tungsten Inert Gas Welding (TIG). However, among the widely used welding technologies in the industries, TIG welding has proven to have achieved remarkably [3]. Notwithstanding, TIG welding also used non-consumable tungsten electrode which are primarily utilized in most of the welding processes that exist [4]. Welding practices itself poses great hazard to the user (welders) such as burns, electric shock, exposure to fumes and gases, noise hazards among others. In order to control metallurgical features as well as weld bead, the application of TIG welding must be in place. However, low productivity will occur as soon as oversize component are used during joining process. A thin layer of activated flux was employed during activated flux TIG welding process to join parts to be welded, and this however produced great penetration depth of the weld. Electron capturing at the outer parts of the arc occurred due to element of high electronegativity and this produces an effect of arc compression which is like what happens during plasma arc welding [4].

TIG welding is basic in situations where in the application, it is important for the control of the metallurgical attributes and the shape of the weld globule. This procedure is, notwithstanding, low in efficiency, especially in the joining of extensive segments. The Activated-flux TIG (ATIG) welding process, created by the Paton Welding Institute during the 1960 s, is a method presently used in increasing the efficiency of the process. A-TIG welding does this by increasing the weld's penetration depth significantly on application of the activated flux in a thin layer on the surfaces to be welded. This impact is, for the most part, associated with electron capture in the outer portions of the arc by highly electronegative components, which choke the bend causing an impact like that utilized in plasma circular segment welding [4]. Halogens such as chlorides, fluorides and oxides. are often used with flux. An increment of the weld depth by a double or more was observed when stainless steel was welded using the TIG welding process, if there is a coating of a thin layer of flux powder primarily coated. Some of the fluxes used in welding include single oxides such as $\mathrm{CaO}, \mathrm{K}_{2} \mathrm{O}_{3}, \mathrm{Na}_{2} \mathrm{O}, \mathrm{TiO}_{2}, \mathrm{Al}_{2} \mathrm{O}_{3}, \mathrm{MgO}$, $\mathrm{SiO}_{2}, \mathrm{MnO}$, single fluorides $\mathrm{CaF}_{2}, \mathrm{NaF}_{2}$, single chlorides $\mathrm{NaCl}$, $\mathrm{CaCl}$. In this experiment, eggshell would be as raw materials to obtain Calcium for the use of flux powder.

Nanocomposites are compounds where one of the phases display dimensions in the nanometer range $\left(1 \mathrm{~nm}=10^{-9} \mathrm{~m}\right)$. These types of materials have developed as appropriate alternatives to by-pass restrictions of micro composites and monolithic, they are stated to the $21^{\text {st }}$ century materials in the view of retaining design distinctiveness and combinations of property that are not established in conventional composites [5]. According to Afolalu et al. [6], today nanocomposites are 
currently being used in numerous fields. This is because they can radically improve the properties of the weld by enhancing the mechanical properties of the weld with strength, modulus, and dimensional stability inclusive. Electrical conductivity is increased, and the gas, water and hydrocarbon permeability are decreased, and other factors such as thermal stability, chemical resistance, surface appearance and optical clarity is improved [7]. Egg Shell powder is an organic waste material which will be used for this investigation. The synthesis of Calcium from the shell will be used in the composition of the calcium oxide flux. The egg is delivered through flying creatures, generally reptiles. In recent, comprehension of the shell of eggs arrangement and lapidification is for the most dependent part on escalated investigations of one animal varieties - the trained chicken gallus. Chicken eggshell constituents were identified [8-10]. This research is therefore aimed at studying the behavioural effect of nano organic flux powder developed from eggshell in TIG welding to improve the overall general quality of welding joints.

The specific objectives of this study among others are to process the pulveriser and energizer through local source, to show that local materials can be used to achieve the effects of industrially produced chemical carburizers, to study the influence of carburization process on the mild steel and at the same time to study the performance of the material after carburization process has taken place.

The novelties in this study among others are that the study involves the processing of eggshell as energizer for strengthening of mild steel, the carburization was carried out using a muffle furnace set at $2000^{\circ} \mathrm{C}$.

In this study, automobile companies and other metal related factories would be needing research like this to further buttress their understanding of metals and how they can be easily finetuned without polluting the environment or costing so much. The discoveries in this investigation additionally affirm that locally source constituents with the essential concoction structure can be utilized to swap mechanically delivered synthetic substances expected for a similar reason. This means reduced cost of the carburization process due to the high price of these industrial chemicals and means that waste domestic materials can be recycled to produce value to the economy.

\section{MATERIALS AND METHODS}

\subsection{Preparation of the metals}

Materials used for the study were, mild steel of grade ASTM A53, galvanized and stainless-steel plates of thickness 10, 6 and $8 \mathrm{~mm}$ respectively, mild steel and stainless-steel rods with thickness $9 \mathrm{~mm}$ length. Eight (8) pieces each of Galvanized, Mild and Stainless-steel plates of $50 \times 50 \mathrm{~mm}$, galvanized and stainless-steel rods of $3.8 \times 28 \mathrm{~mm}$ length were prepared and used for the study. Developed nano-flux welding powder from agrowaste (Egg Shell) and imported flux welding powder were introduced using TIG welding. Two types of fluxes (Easy-Flo flux powder and the calcium oxide flux powder which has been developed) were used to observe and study methodically the effect of the fluxes on the metal and rods. Egg shell and the pulverized powder contains a good measure of calcium carbonate simply like periwinkles, snails (shells), and others in that mollusk family. In this study, eggshell is used as a carburizing agent also serving the purpose of an energizer. This is because of its calcium carbonate content, availability, and cost effectiveness. Welding conditions used were with flux from the locally developed calcium oxide powder and with an imported Easy Flo-flux powder.

This study would bring about cheaper costs in welding and also create a friendly environment due to the oxidation gases being replaced with flux powder

- Recycling of organic waste materials for the development process of creating flux powder for TIG welding.

Tests carried out on welded samples include Brinell hardness tests, tensile tests, microstructural analysis using Scanning Electron Microscope (SEM).

\subsection{Compositional analysis test}

The compositional analysis of the grade steel (ASTM A53) metal used in this study is depicted in Table 1.

Table 1. Compositional analysis

\begin{tabular}{cc}
\hline Rudiments & Configuration \\
\hline Carbon & $0.251 \%$ \\
Silicon & $0.852 \%$ \\
Magnesium & $0.951 \%$ \\
Potassium & $0.051 \%$ \\
Sulfur & $0.144 \%$ \\
Chromium & $0.382 \%$ \\
Nickel & $0.210 \%$ \\
Molybdenum & $0.206 \%$ \\
Aluminium & $0.022 \%$ \\
\hline
\end{tabular}

\subsection{Development of flux powder from eggshell}

In this paper, the test materials used in this present investigation were brown eggshell powder which has a moisture content of $0.20 \%$ and $33.13 \%$ of calcium, mostly used for biodiesel production, fertilizer, calcium supplement, biomaterial for bone tissue replacements applications and 100.09 grams of Calcium Carbonate $\left(\mathrm{CaCO}_{3}\right)$ that was precipitated heavily in BDH Laboratory Supplies, located in Poole, England. About 483 eggshells were shredded into smaller bits with a mortar and pestle and placed in a crucible blast furnace with a thermal heat capacity of up to $2300^{\circ} \mathrm{C}$, however the furnace was set to fire for 3 hours at a temperature of $2000^{\circ} \mathrm{C}$ for this experiment. The ashes were left to cool for almost 10 hours before being sieved with a sieve shaker to separate increasingly large particles from the correct particle sizes. The synthesis process involved the combining of the constituent elements of separate material. The apparatus required is a mass balance which was used in measuring the weight in grams of the Calcium Carbonate salt and ashes of the egg shell. This experiment was conducted in the biochemistry laboratory in the building of Science and Technology in Covenant University in Ota, Ogun state, Nigeria. On the mass balance, 50 grammes of ashes were weighed before being placed in a beaker with 100 grammes of salt and $1000 \mathrm{ml}$ of distilled water, which was measured with a measuring cylinder. This mixture was thoroughly stirred in a beaker with a magnetic stirrer before being placed on a Stuart hot plate. The mixture was allowed to revolve in a clockwise motion for an estimated time of one hour. The centrifugation procedure is a technique for separating particles from a solution based on their size, shape, density, medium viscosity, and rotor speed. In a centrifuge tube, the particles are suspended in a liquid media. After that, the tube is inserted in a rotor and revolved at a specific speed. The solution had been 
allowed to settle in the keg for 24 hours prior to the centrifugation operation. This experiment was conducted in Research laboratory in Covenant University in Ota, Ogun state, Nigeria. The solution was filled inside 12 tubes with a size of in which these tubes were placed inside a laboratory centrifuge and was allowed to spin for an estimated time of 15 minutes. This process occurred repeatedly till the solution was exhausted. The drying and calcination process involves putting the powder inside the oven at $500^{\circ} \mathrm{C}$ for two days for mere drying of the powder removing all the water content and moisture completely, this is known as the drying process. Furthermore, pure calcium oxide is then derived through the calcination process. This is a thermal heat treatment process in the absence or limited supply of the composition of $20.95 \%$ $\mathrm{O}_{2}, 78.09 \% \mathrm{~N}_{2}, 0.93 \% \mathrm{AR}, 0.04 \% \mathrm{CO}_{2}, 0.4 \%$ water vapor and little amount of other gases, whereby all the impurities found in the powder will be removed inside the muffle furnace at $500^{\circ} \mathrm{C}$.

\subsection{Application of flux powder}

The faces to be welded were grinded to be very smooth for the best results. The setup was TIG welding. The equipment used in welding is shown below in Figure 1a. The imported flux and calcium oxide flux were mixed with water and little drops of liquid detergent to form a thick paste. This paste was then applied using a brush with a width of $10 \mathrm{~mm}$ to the joint surfaces of the metal plates and rods before the assembly. The three welding conditions were with Calcium oxide, with easyflo flux powder and without flux.

\subsection{Welding parameters}

Table 2. Welding parameters for the experiment

\begin{tabular}{ccccc}
\hline Metals & $\begin{array}{c}\text { Current } \\
(\mathbf{A})\end{array}$ & $\begin{array}{c}\text { Voltage } \\
(\mathbf{V})\end{array}$ & $\begin{array}{c}\text { Arc } \\
\text { gap }\end{array}$ & $\begin{array}{c}\text { Gas flow } \\
\text { rate }\end{array}$ \\
\hline $\begin{array}{c}\text { Stainless steel } \\
\text { Galvanized }\end{array}$ & 36 & 51 & 5 & 8 \\
steel & 32 & 51 & 5 & 8 \\
Mild steel & 36 & 51 & 5 & 8 \\
Stainless rod & 31 & 36 & 4 & 7 \\
Mild rod & 30 & 36 & 4 & 7 \\
\hline
\end{tabular}
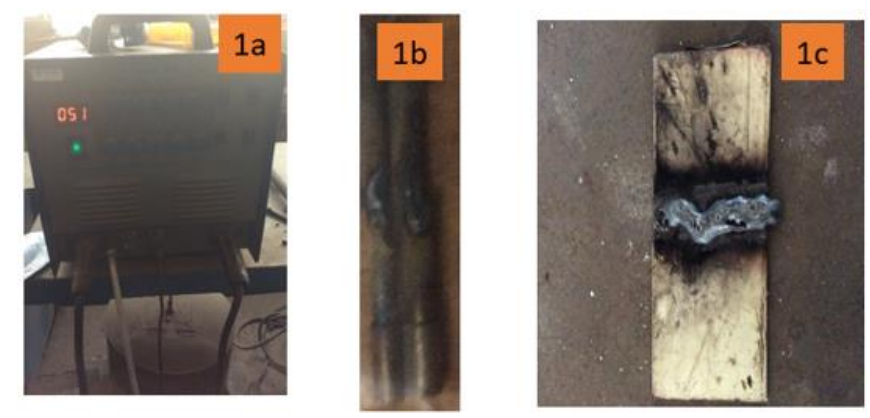

Figure 1. (a) TIG welding machine (b) Mild rod (c) Mild steel plate

The welding type used in this experiment was Tungsten Inert Gas Welding (TIG) (see Figure 1a) and the mild steel rod and the welded mild steel plate are shown in Figure 1b and c respectively. The welding parameters considered during this study were Current (32 - 36 A), Voltage (51 V), Arc gap (5 $\mathrm{mm}$ ) and Gas flow rate (8). Details of the parameter spread across welding conditions is as shown in Table 2.

\section{RESULTS AND DISCUSSION}

\subsection{Tensile test}

The tensile test results show that the developed flux powder produced displayed a tensile stress of $88.14 \mathrm{MPa}$ for mild steel and stainless-steel welds whereas for the stainless and mild steel rods without the application of any flux which withheld a maximum tensile stress of 117.705 and $11.793 \mathrm{MPa}$ respectively (See Table 3). Furthermore, for the imported flux powder, mild steel and stainless-steel rods appeared to be 162.645 and 55.195 MPa respectively (see Table 4). The graph shown in Figure 2a is the stress strain curve for the developed flux while Figure $2 b$ shows the stress-strain curve of TIG welding with imported flux.

\subsubsection{Stress and strain graphs}

The mild steel had a higher tensile stress for imported flux as compared to stainless steel, but the values for the maximum tensile strength for the developed flux powder for both mild steel and stainless steel are almost the same (see Tables 3 and 4).

The tensile strain of the imported flux of both mild and stainless steel are both lower when compared to that of the developed flux. Furthermore, without the application of any flux, the stainless-steel maximum tensile stress at load, maximum tensile stress and strain supersedes the developed and imported flux powder whereas the mild steel appears to be contrary having the maximum tensile stress at load, maximum tensile stress and strain to be lower than that of imported and developed flux powder.
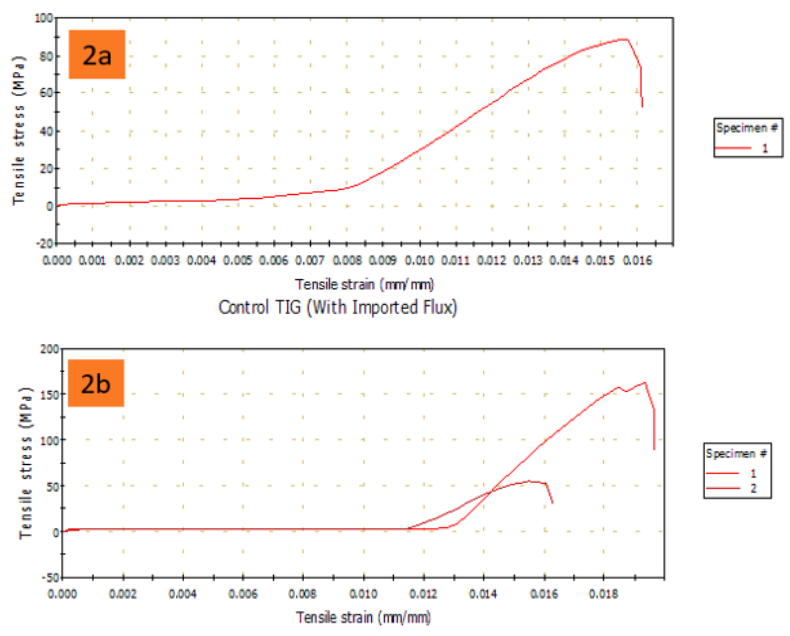

Figure 2. Stress-strain curve of TIG welding of (a) developed flux (b) 1-Imported, 2-Control

The conducted experiment on the TIG welds without the use of any flux powder (Control sample) has appeared to have the least tensile stress as shown in Figure $2 b$ (number 2). The maximum tensile stress after experimentation revealed the imported flux on the application of the TIG weld to be 162.64451 MPa as shown in Figure 2b (number 1). A result of maximum tensile strength of the locally developed flux after experimentation appeared to be 88.13564 Mpa due to variation as there were several interruptions during the welding process. The tensile load at break and tensile strain at break are 845.962 $\mathrm{N}$ and $0.01609 \mathrm{~N}$, respectively. Furthermore, the modulus (Emodulus) is $12029.406 \mathrm{Mpa}$ having the tensile extension at break to be $0.4505 \mathrm{~mm}$. 
Table 3. The results of tensile experiment for TIG-welds of mild steel rods

\begin{tabular}{cccc}
\hline Parameters & $\begin{array}{c}\text { Developed flux } \\
\text { powder }\end{array}$ & $\begin{array}{c}\text { Imported flux } \\
\text { powder }\end{array}$ & Control \\
\hline $\begin{array}{c}\text { Load at Maximum } \\
\text { Tensile Stress (N) }\end{array}$ & 999.559 & 1844.5756 & 133.7416 \\
$\begin{array}{c}\text { Maximum Tensile Stress } \\
(\mathrm{MPa})\end{array}$ & 88.136 & 162.6445 & 11.7926 \\
$\begin{array}{c}\text { Maximum Tensile Strain } \\
(\mathrm{mm} / \mathrm{mm})\end{array}$ & 0.0155 & 0.01935 & 0.0092 \\
\hline
\end{tabular}

Table 4. The results of tensile experiment for TIG-welds of stainless-steel rods

\begin{tabular}{cccc}
\hline Parameters & $\begin{array}{c}\text { Developed flux } \\
\text { powder }\end{array}$ & $\begin{array}{c}\text { Imported flux } \\
\text { powder }\end{array}$ & Control \\
\hline $\begin{array}{c}\text { Load at Maximum } \\
\text { Tensile Stress (N) }\end{array}$ & 999.559 & 625.9774 & 1334.9073 \\
$\begin{array}{c}\text { Maximum Tensile } \\
\text { Stress (MPa) }\end{array}$ & 88.136 & 55.1952 & 117.7048 \\
$\begin{array}{c}\text { Maximum Tensile } \\
\text { Strain (mm/mm) }\end{array}$ & 0.0155 & 0.01548 & 0.01934 \\
\hline
\end{tabular}

\subsection{SEM test results}

Figure 3a shows a graphical representation of a SEM micrograph without the use of any flux powder. It is evident in the image that the distance during experimentation between the sample surface and the lower end of the pole piece where the sample is coming from is $9.4 \mathrm{~mm}$. This specimen displays a very plain structure with minimal radial pattern, uniformity and distortion as compared with the other SEM micrographs of the imported and developed flux. Figure $3 b$ shows a graphical representation of a SEM micrograph with the use of imported flux powder. This micrograph displays a distortion in its arrangement, having a smooth radial pattern and uniformity along its path $[11,12]$. Figure $3 \mathrm{c}$ shows a graphical representation of a SEM micrograph with the use of developed flux. The image displays a very low level of distortion in comparison but very high level of diffraction and radial patterns in the micrograph as compared to the micrograph of imported flux and without the use of any flux. Summarily, the weld made with the nano- flux powder have a relatively smooth surface when compared to the weld without flux and the weld with imported flux $[13,14]$.
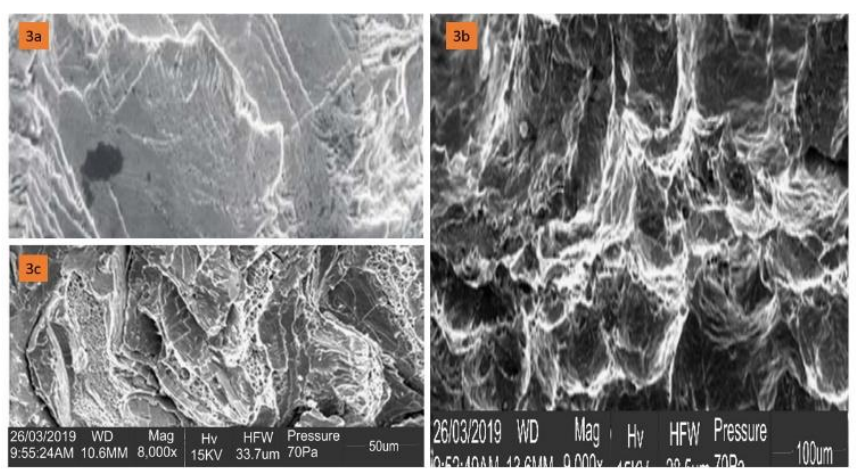

Figure 3. SEM Micrograph of TIG (a) without Flux (b) with Flux (c) with developed Flux

\subsection{Hardness test}

As seen in Table 5, hardness value obtained for the threeweld zone (base metal, weld joint and heat affected zone) for galvanized steel were $111.95,111.16$ and $131.59 \mathrm{BHN}$ when the imported flux was used, 96.62, 120.30 and 182.99 BHN when no flux was used and 90.95, 97.61 and 98.92 with the use of the developed flux during the welding of the joints. This result shows that the developed flux does not prove to have higher hardness compared to the imported flux and control. Hence, the mechanical properties of this weld would have high ductility, elasticity, malleability and low brittleness, resilience, and stiffness with the application of the developed flux and this is in consonant with the work reported in Ref. [15].

Table 5. Hardness test for TIG for galvanized plates

\begin{tabular}{cccc}
\hline Samples & $\begin{array}{c}\text { Base metal } \\
\text { (BHN) }\end{array}$ & $\begin{array}{c}\text { Welded joint } \\
\text { (BHN) }\end{array}$ & $\begin{array}{c}\text { Heat affected zone } \\
\text { (BHN) }\end{array}$ \\
\hline $\begin{array}{c}\text { Developed } \\
\quad \text { Flux }\end{array}$ & 90.95 & 97.61 & 98.92 \\
Imported Flux & 111.95 & 111.16 & 131.59 \\
$\quad$ Control & 96.62 & 120.30 & 182.99 \\
\hline
\end{tabular}

Table 6. Hardness test for TIG for mild steel plates

\begin{tabular}{cccc}
\hline Samples & $\begin{array}{c}\text { Base metal } \\
(\mathrm{BHN})\end{array}$ & $\begin{array}{c}\text { Welded joint } \\
(\mathrm{BHN})\end{array}$ & $\begin{array}{c}\text { Heat affected } \\
\text { zone }(\mathrm{BHN})\end{array}$ \\
\hline $\begin{array}{c}\text { Developed } \\
\text { Flux }\end{array}$ & 187.99 & 164.84 & 79.22 \\
$\begin{array}{c}\text { Imported } \\
\text { Flux }\end{array}$ & 143.36 & 108.85 & 110.56 \\
Control & 206.21 & 151.67 & 78.24 \\
\hline
\end{tabular}

For mild steel in Table 6, hardness value obtained for the three weld zones (base metal, weld joint and heat affected zone) for mild steel were $187.99,164.84$ and $79.22 \mathrm{BHN}$ when the developed flux was used, 143.36, 108.85 and 110.56 BHN when the imported flux was used and 206.21, 151.67 and 78.24 when no flux was used during the welding of the joints. The hardness in the base metal, when nano- flux powder was used is 187.99 BHN, when imported flux was used it was 143.36 BHN and when no flux was used it was 206.21 BHN. For welded joint, the hardness value was 164.84 when the developed flux was used, 108.85 when the imported flux was used and 151.67 when no flux was used, and the recorded values are in agreement with the work reported in Ref. [16]. This shows that the nano- flux powder has higher hardness than when imported flux was used only at the welded joint.

\section{CONCLUSION}

The investigation of morphology characterization and mechanical properties of nano-flux powder (from eggshell) for TIG welding has been carried out. The results obtained aided the drawing of the following conclusions.

1. The developed nano- flux powder had a better effect in TIG welding of galvanized and mild steel when compared with the welded joints from imported flux or when no flux was used.

2. Egg shells being regarded as a Nano-organic waste and a nuisance to the environment, it can now be recycled and developed into a flux powder to produce high quality weld 
which can serve as a substitute for costly imported flux powder for welding processes.

3. The welded joints produced using the developed nano- flux powder was found to have highest hardness values of $164.84 \mathrm{BHN}$ compared with the imported flux and weld without flux samples.

4. Results of microstructural analysis using of SEM have revealed an improvement in the microstructural properties of the weld with the application of the nano- flux as compared to the imported flux and control weld.

\section{ACKNOWLEDGMENT}

The author acknowledged Covenant University for the financial support offered for the publication of this research.

\section{REFERENCES}

[1] Karadeniz, E., Ozsarac, U., Yildiz, C. (2007). The effect of process parameters on penetration in gas metal arc welding processes. Materials \& Design, 28(2): 649-656. https://doi.org/10.1016/j.matdes.2005.07.014

[2] Singh, B., Khan, Z.A., Siddiquee, A.N. (2013). Review on effect of flux composition on its behavior and bead geometry in submerged arc welding (SAW). Journal of Mechanical Engineering Research, 5(7): 123-127. https://doi.org/10.5897/JMER2013.0284

[3] Adetunji, O.R., Adegbola, A.O., Afolalu, S.A. (2015). Comparative study of case-hardening and waterquenching of mild steel rod on its mechanical properties. International Journal of Advance Research, IJOAR, 3(6): $1-9$.

[4] Omiogbemi, I.M.B., Yawas, D.S., Dagwa, I.M., Okibe, F.G. (2017). Effects of metal inert gas welding parameters on some mechanical properties of austenitic stainless steel in acidic environment. Nigerian Journal of Technology, 36(3): 835-843. https://doi.org/10.4314/njt.v36i3.25

[5] Udo, M.O., Esezobor, D.E., Apeh, F.I., Afolalu, A.S. (2018). Factors affecting ballability of mixture iron ore concentrates and iron oxide bearing wastes in metallurgical processing. Journal of Ecological Engineering, $\quad$ 19(3): $235-242$ https://doi.org/10.12911/22998993/86158

[6] Afolalu, S.A., Okokpujie, I.P., Salawu, E.Y., Abioye, A.A., Abioye, O.P., Ikumapayi, O.M. (2018). Study of the performances of nano-case treatment cutting tools on carbon steel work material during turning operation. In AIP Conference Proceedings, 1957(1): 1-6. https://doi.org/10.1063/1.5034331

[7] Chen, S., Jiang, F., Lu, Z., Tao, D., Yu, Y. (2011). Measurement and analysis of the welding arc current density and pressure distribution based on split anode method. In 2011 IEEE International Conference on Mechatronics and Automation, pp. 1544-1549. https://doi.org/10.1109/ICMA.2011.5985979

[8] Krithiga, G., Sastry, T.P. (2011). Preparation and characterization of a novel bone graft composite containing bone ash and egg shell powder. Bulletin of Materials $\quad$ Science, $34(1)$ : $177-181$. https://doi.org/10.1007/s12034-011-0044-1

[9] Bogdanov, A.G., Gromushkin, D.M., Kokoulin, R.P., Mannocchi, G., Petrukhin, A.A., Saavedra, O., Yashin, I.I. (2010). Investigation of the properties of the flux and interaction of ultrahigh-energy cosmic rays by the method of local-muon-density spectra. Physics of Atomic Nuclei, 73(11): 1852-1869. https://doi.org/10.1134/S1063778810110074

[10] Ikumapayi, O.M., Okokpujie, I.P., Afolalu, S.A., Ajayi, O.O., Akilabi, E.T., Bodunde, O.P. (2018). Effects of quenchants on impact strength of single-vee butt welded joint of mild steel. In IOP Conference Series: Materials Science and Engineering, 391(1): 012007. https://doi.org/10.1088/1757-899X/391/1/012007

[11] Afolalu, S.A., Samuel, O.D., Ikumapayi, O.M., Oladipupo, S.I., Emetere, M. (2020). Study of mechanical behavious and characterization of a steel joints in MIG Welding under varying fluxes. International Journal of Engineering Research and Technology, 13(6): 1300-1306.

[12] Afolalu, S.A., Samuel, O.D., Ikumapayi, O.M. (2020). Development and characterization of nano-flux welding powder from calcined coconut shell ash admixture with $\mathrm{FeO}$ particles. Journal of Materials Research and Technology, 9(4): 9232-9241. https://doi.org/10.1016/j.jmrt.2020.06.067

[13] Akinlabi, E.T., Osinubi, A.S., Madushele, N., Akinlabi, S.A., Ikumapayi, O.M. (2020). Data on microhardness and structural analysis of friction stir spot welded lap joints of AA5083-H116. Data in Brief, 33: 106585. https://doi.org/10.1016/j.dib.2020.106585

[14] Oladapo, B.I., Daniyan, I.A., Ikumapayi, O.M., Malachi, O.B., Malachi, I.O. (2020). Microanalysis of hybrid characterization of PLA/cHA polymer scaffolds for bone regeneration. Polymer Testing, 83: 106341. https://doi.org/10.1016/j.polymertesting.2020.106341

[15] Rao, T., Krishna, G., Kumar, M. (2019). Investigation of microstructure and mechanical properties of MIG welded mild steel plates. Ann. Chim. Sci. Mat, 43: 257-263. https://doi.org/10.18280/acsm.430409

[16] Chikodi, D.M.C., Nnamdi, O.D.O., Sunday, A.V. (2021). Anti-wear and Hardness Values of Functional ValueAdded Zn-ZnO-Rice Husk Ash Composite Coating of Mild Steel. Revue des Composites et des Matériaux Avancés, 31(1): 27-32. https://doi.org/10.18280/rcma.310104 